\title{
Our Own Devices: The Past and Future of Body Technology.
}

By Edward Tenner. New York: Alfred A. Knopf, 2003. Pp. xviii+314. \$26.

"Everyday technology sometimes reshapes the body; the feet of shod people are different from the feet of those who have always walked barefoot. APRIL More important, it helps shape how we use our bodies. Technology, and the techniques of using it, have coevolved over millennia." With these words, which succinctly sum up his thesis, Edward Tenner begins the epilogue to Our Own Devices, a book that takes the reader on a tour among baby bottles and desk chairs, sneakers and keyboards, and much more. Each chapter focuses on one specific set of artifacts, and each backs up and repeats Tenner's thesis. This is what holds the book together, an accomplishment which otherwise might have been difficult considering the great variety of technologies discussed.

It is not his thesis that makes Tenner's book worthwhile, however. One hardly needs to provide elaborate illustrations to convince historians of technology of the mutual shaping of technology and use/users. What keeps the reader's attention is the recognition of everyday things that we all know and at times have used, combined with multitudes of minute, sometimes funny, sometimes shocking details. These particulars offer new views on objects that have become so commonplace that they truly deserve to be called "our own devices."

At the same time, all these facts and fine points leave the reader thirsting for more. Baby bottles and their contents deserve a book of their own, just like desk chairs and running shoes — with even more details and depth, and also more pictures. In the limited space each of Tenner's chapters provides, it is not possible to fully satisfy the curiosity provoked by his descriptions of our mundane surroundings. In that respect, this book is very similar to James Meyer's 1978 Eggplants, Elevators, Etc.: An Uncommon History of Common Things. Although Tenner's work relies more on accurate research and less on anecdote, the similarities between these two books are remarkable: neither is exhaustive in reference to its topics, and both of them exhaust. It is hard work getting through such encyclopedic tomes; one does not read from automobiles to vanilla (Meyers) in one sweep, nor from bottles to helmets (Tenner).

Still, if Tenner meant his book to be just a fact-finder and storyteller concerned with a haphazard selection of interesting things, he succeeded. It is an entertaining book, fascinating to leaf through and at times read a whole chapter. Judging from the epilogue, however, Tenner wants to make a point about his book transcending his simple delight in technology (or sometimes his dismay). The problem is that this point is not sufficiently interesting to carry the reader through the book, and that problem is intensified by the lack of logical structuring. In "The First Technology," for 
example, Tenner defends his choice of artifact on the grounds that "as common as prenatal tests have become ... they have a small effect on the human body compared with those of an older form of intervention in our development: bottle-feeding" (p. 31) —and then he sets off on a description of human lactation and its assistive technologies. Similarly, Tenner introduces footwear as "the first rite of technical passage for the greater part of humanity" (p. 51), posture chairs as being "to the back what shoes are to the feet" (p. 104), and keyboards as "being to the fingers as chairs are to the back" (p. 161). There is nothing to assist the reader in understanding why perchance these topics made it on to Tenner's pages in this particular sequence. An argument built along the lines of Wiebe Bijker's Of Bicycles, Bakelite and Bulbs would have helped the reader through Tenner's odd assortment.

So, Our Own Devices disappoints as a theoretical study. But read simply as a collection of essays it offers a good introduction to each of its nine topics. And, as a compilation of stories about technologies close to our bodies and our lives, Our Own Devices amuses thoroughly.

LARA TAURITZ BAKKER

Lara Tauritz Bakker is a Ph.D. candidate at the Center for Studies of Science, Technology and Society of the University of Twente, the Netherlands. Her research interests lie in the development and use of everyday technologies such as desk chairs, automatic tellers, and digital blood-glucose meters.

\section{Where Stuff Comes From: How Toasters, Toilets, Cars, Computers and Many Other Things Come to Be As They Are.}

By Harvey Molotch. London and New York: Routledge, 2003.

Pp. xii+324. \$24.95.

Many books deserve a second reading, and while Where Stuff Comes From is not in that category, this does not mean it should not be read a first time. At least in part, sociologist Harvey Molotch succeeds in demystifying the creativity and constraints that impel or impede products ("stuff") on their way to market. His account is based on some four years of interviews with and observation of industrial designers; and even though his sample is relatively small, geographically localized, and nonrandom, it reflects the nature and goals of the profession (he describes his methodology on pp. 264-65, note 2). As he makes clear, while every product is designed, however well or badly, at least in the United States industrial design is little known as a profession, and most of its practitioners are poorly paid and anonymous. Those with reputations as product designers tend to be dead (such as Raymond Loewy) or to have established that reputation in another field (the architect Michael Graves). The situation is apparently less dire in Great Britain and on the Continent.

Molotch's style is conversational and energetic; he is entertaining with- 